DOI: 10.17951/lrp. 2018.37.1.95-109

\author{
SABINA GUZ
}

Uniwersytet Marii Curie-Skłodowskiej w Lublinie

\title{
DZIECKO I DZIECIŃSTWO \\ W PERCEPCJI DZIECI KOŃCZĄCYCH EDUKACJĘ PRZEDSZKOLNĄ I WCZESNOSZKOLNĄ
}

Streszczenie: Dziecko i dzieciństwo to kategorie, które trudno jest jednoznacznie określić. Przybierają one bowiem różne znaczenia zależnie od zmieniających się okresów historycznych, kręgów kulturowych i środowiskowych oraz teorii naukowych, rozwijanych w ramach różnych dyscyplin badawczych. Znaczenia te w istotny sposób rzutują na sytuację dziecka w społeczeństwie w określonym miejscu i czasie, a także na kształt i jakość jego relacji z osobami dorosłymi oraz nabywane przez nie doświadczenia życiowe. Przedstawione w opracowaniu badania ukazują, jaki obraz dziecka i dzieciństwa ukształtował się w świadomości współczesnych dzieci kończących edukację przedszkolną i wczesnoszkolną. Podstawę do nakreślenia tego obrazu stanowiła analiza odpowiedzi dzieci na pytania zadane im w czasie indywidualnych rozmów.

Słowa kluczowe: dziecko, dzieciństwo, okresy życia

\section{WPROWADZENIE}

Dziecko i dzieciństwo to terminy, które niełatwo jest w sposób jednoznaczny zdefiniować. Ich pojmowanie przekształca się wraz z historycznymi zmianami, dokonującymi się w społeczeństwie. W literaturze podkreśla się, że dzieciństwo jest konstruktem historycznym, który jest uwarunkowany zmianami politycznymi, społecznymi, kulturowymi cechującymi daną epokę. Zależy ono również od dominujących w określonym miejscu i czasie poglądów filozoficznych i pedagogicznych (zob. m.in.: Aries 2010; Matyjas 2008; Segiet 2011; Nowak 2013). Na to jak postrzegane jest dziecko i dzieciństwo rzutują nie tylko znaczące w danym okresie i przestrzeni czynniki gospodarcze, polityczne, religijne, ale też wiele innych, takich jak np.: struktura demograficzna ludności, rasa, płeć, klasa społeczna 
(Didkowska 2015). Zależnie od nich wszystkich zmienia się sytuacja dzieci w społeczeństwie. Każdą epokę charakteryzują inne relacje dziecka ze społeczeństwem, inne oczekiwania i poglądy dorosłych dotyczące dzieci i dzieciństwa, inne prawne i organizacyjne rozwiązania opieki, wychowania oraz edukacji młodego pokolenia.

Najogólniej rzecz ujmując, w historii zmieniającego się podejścia do dzieci i dzieciństwa wyróżnia się trzy dominujące, następujące po sobie postawy (Appelt 2001). Pierwsza z nich przypadała na epokę cywilizacji greckiej i rzymskiej oraz średniowiecze. Charakteryzowało ją uznawanie znaczącej roli dzieciństwa dla późniejszego rozwoju jednostki. Dlatego wysoko ceniona była wczesna edukacja, ale tylko dla dzieci z wybranych warstw społecznych, która prowadzona była według ściśle określonych zasad. W starożytności zajmowało się nią państwo, a w średniowieczu - Kościół. Z drugiej strony status i sytuacja większości dzieci były nie do pozazdroszczenia, bowiem równocześnie istniało powszechne przyzwolenie na praktyki surowego karania, wręcz maltretowania dzieci, handlowania nimi, zmuszania do ciężkich domowych i publicznych prac, wykorzystywania seksualnego, a nawet dzieciobójstwa. Można więc powiedzieć, że w ówcześnie dzieciństwo, w naszym współczesnym rozumieniu, nie istniało, a życie dzieci było bardzo trudne (Vasta i in. 1995).

Dla drugiej postawy, która rozwijała się od renesansu przez reformację, oświecenie aż do współczesności, charakterystyczne jest zauważanie i szanowanie dziecka oraz przejawianie chęci jego formowania według reguł ustanowionych przez dorosłych, a także wyodrębnienie okresu dzieciństwa przed wkroczeniem dziecka w świat dorosłych. Wtedy to pojawia się zainteresowanie dobrem dziecka, jego rozwojem, w tym rozwojem moralnym, a także postępami w nauce. Terminowanie zostaje zastąpione przez szkołę stanowiącą okres przygotowawczy przed wejściem dziecka w dorosłe życie, która stopniowo staje się coraz bardziej dostępna dla młodego pokolenia pochodzącego z różnych warstw społecznych.

Zgodnie z trzecią postawą, charakterystyczną dla współczesności, dziecko uznawane jest za równowartościowego partnera $\mathrm{w}$ relacjach $\mathrm{z}$ dorosłym. Jest ono nie tylko kształtowane przez dorosłych, ale również samo wnosi swój wkład w kontakty z nimi. Aktualnie często akcentuje się, iż w postawach społeczeństwa wobec dziecka i dzieciństwa nastąpił wyraźny postęp. Od cywilizacji, w której rodzice nie umieli czy też nie chcieli dojrzeć w dzieciach odrębnych istot ludzkich, posiadających specyficzne potrzeby, po czasy, kiedy dominuje postawa polegająca na postrzeganiu dzieci jako osoby odmienne, autonomiczne i zasługujące na szczególną opiekę, troskę i odpowiednie wsparcie ze strony dorosłych.

Współcześnie odrzuca się podział życia człowieka na dwa główne okresy: dziecko i dorosły i przyjmuje, iż dziecko niemal od początku jest aktywnym podmiotem działającym w społeczeństwie, z własnymi prawami oraz obowiązkami. 
W związku z tym podkreśla się, że wszelkie relacje społeczne dziecko-dorosły powinny być relacjami dwukierunkowymi, opartymi na dialogu i współpracy obu podmiotów, które dzielą się ze sobą wiedzą, umiejętnościami i doświadczeniem. Dlatego ważne jest uznanie pełnej podmiotowości dziecka, które różni się od osoby dorosłej tylko poziomem kompetencji w różnych sferach funkcjonowania. Zwraca się na to uwagę zwłaszcza w teorii, natomiast w praktyce wychowania i edukacji założenia te nie zawsze są realizowane.

Zauważyć jednakże w tym miejscu należy, iż współcześnie istnieją różne sposoby bycia dzieckiem i różne rodzaje dzieciństwa. Charakter i jakość dzieciństwa zależy bowiem od wielu czynników, zjawisk i procesów zachodzących w środowisku życia dziecka oraz w skali globalnej. Mają na nie m.in. wpływ przemiany dokonujące się we współczesnej rodzinie, w tym zmiany w jej strukturze (jedynactwo dzieci, rozpad, rozkład i rekonstrukcje rodziny), praca zawodowa rodziców i w związku z tym częsta i niekiedy długotrwała ich nieobecność w domu czy też ich bezrobocie, niepełnosprawność, bieda, bezradność lub inne zjawiska destrukcyjne bądź patologiczne (przewlekłe choroby, alkoholizm, narkomania, przemoc itp.). Mogą one negatywnie odbić się na jakości dzieciństwa ze względu na trudności w optymalnym zaspokajaniu przez rodziców potrzeb dziecka i prawidłowym pełnieniu opiekuńczo-wychowawczych i społecznych funkcji rodziny. Dlatego współcześnie uważa się, że dobre dzieciństwo, upływające w warunkach sprzyjających harmonijnemu rozwojowi dziecka, stanowi nieoceniony kapitał, który wnosi ono w dorosłe życie. Dzieciństwo bowiem to zespół określonych doświadczeń, świat przeżyć i aktywności zapisujący się w biografii jednostki, mający znaczenie w kształtowaniu się jej tożsamości. Ich źródłem jest bliskie i dalsze środowisko życia dziecka (rodzina, rówieśnicy, szkoła, instytucje wychowania pozaszkolnego, środowisko lokalne, media). Wszystkie one mogą w istotny sposób wpływać na kształtowanie się przyszłych nastawień dziecka wobec świata i ludzi (Smolińska-Theiss 1993).

Dziecko i dzieciństwo są przedmiotem zainteresowań różnych dyscyplin naukowych. Kategorie te badane są z różnych punktów widzenia przez historyków, filozofów, psychologów, socjologów, pedagogów i przedstawicieli innych nauk. Opisywana jest historia i teraźniejszość dzieciństwa w różnych społeczeństwach i kulturach. Badane i analizowane jest ono jako faza życia człowieka, obszar wpływów wiążących dziecko z instytucjami edukacyjnymi i grupami zawodowymi, które zajmują się edukacją, jako teren oddziaływań politycznych, ekonomicznych, światopoglądowych, medialnych podejmowanych z punku widzenia statusu i uczestnictwa dziecka w życiu społecznym oraz podziału dóbr i środków materialnych. Wiele jest również badań nad dzieciństwem prowadzonych z punktu widzenia środowiskowych uwarunkowań życia i rozwoju dziecka. Badania te są podstawą kreślenia obrazu dzieciństwa przebiegającego w różnych miejscach i czasie, roz- 
poznawania warunków życia dziecka, a także ukazywania go jako aktywnego członka i obserwatora życia społecznego (Smolińska-Theiss 1993, 2010). Na różne zakresy badań nad dzieckiem i dzieciństwem wskazuje również Bogusław Śliwerski (2007). Wyróżnia on bowiem w badaniach nad tymi kategoriami nurt historyczny, etnologiczny i konstruktywistyczny.

Przedstawione rozważania wskazują, jak trudno jest w zadowalający sposób określić, kim jest dziecko i czym jest dzieciństwo. Problem ten wynika z wielości znaczeń nadawanych tym pojęciom w różnych okresach historycznych, kręgach kulturowych, teoriach pedagogicznych i środowiskach społecznych. Znaczenia te rzutują na kształt, jaki przyjmują prywatne koncepcje dziecka i dzieciństwa każdej osoby dorosłej, w tym wychowawców, nauczycieli i rodziców. Jest to sprawa ważna, ponieważ to często one w największej mierze decydują, jakiego rodzaju relacje nawiązują się między dorosłymi a dziećmi.

Podstawy kształtowania się prywatnych poglądów na dziecko i dzieciństwo mogą być bardzo różne, podobnie jak różne są źródła wiedzy naukowej na temat tych kategorii pojęciowych. Należą do nich m.in. analiza i interpretacja: wytworów ikonograficznych, traktatów wybitnych myślicieli, dzieł naukowych pedagogów i psychologów oraz innych uczonych, utworów literackich, wydawnictw encyklopedycznych i słownikowych, zbiorów przysłów i sentencji, a także aktów prawnych i innych dokumentów. Wymienione źródła są szczególnie cenne w badaniach historycznych. W przypadku zaś współczesności informacji o dziecku i dzieciństwie oraz ich postrzeganiu przez dorosłych dostarcza analiza ich wypowiedzi formułowanych w różnych sytuacjach, a także obserwacja ich zachowania w kontaktach z dziećmi. Innym źródłem mogą być również same dzieci. Obraz współczesnego dziecka i dzieciństwa przedstawiany oraz kreowany jest także przez media (prasa, radio, telewizja, Internet, reklamy z udziałem dzieci). O dużych różnicach w przedstawianiu dziecka i dzieciństwa, zależnie od tego, kto wypowiada się na ten temat i na jakich źródłach się opiera, pisze m.in. Jolanta Zwiernik (2008).

\section{BADANIA WŁASNE}

Referowane w opracowaniu badania empiryczne inspirowane były następującymi pytaniami głównymi:

1. Jak postrzegane jest dziecko i dzieciństwo przez dzieci objęte edukacją przedszkolną i wczesnoszkolną?

2. Czy i w jaki sposób postrzeganie dziecka i dzieciństwa różni się w zależności od wieku i etapu edukacji dzieci oraz ich płci i środowiska lokalnego (miasto, wieś)? 
W szczególności zmierzały one do ustalenia:

- $\quad$ kogo, zdaniem badanych, można nazwać dzieckiem;

- jak długo jest się dzieckiem;

- jak, zdaniem dzieci, można określić dzieciństwo;

- $\quad$ co robi się w tym okresie życia;

- jaka jest atrakcyjność doświadczanego aktualnie dzieciństwa w porównaniu z wiekiem niemowlęcym oraz dorosłością;

- $\quad$ co jest powodem tego, że wymienione wyżej okresy życia są dla badanych dzieci atrakcyjne lub nieatrakcyjne;

- jaki zakres swobody i samodzielności przypisują dzieci dzieciństwu;

- jakie są, zdaniem badanych, powinności i ograniczenia w dzieciństwie;

- jakie są dziecięce marzenia, powody do radości oraz zmartwienia.

W celu poznania obrazu dziecka i dzieciństwa, ukształtowanego w świadomości dzieci kończących edukację przedszkolną i wczesnoszkolną, przeprowadzono z nimi rozmowy indywidualne, ukierunkowane wcześniej przygotowanymi pytaniami. Większość pytań miała charakter otwarty. Pozwalały one na samodzielne formułowanie odpowiedzi, które w toku analizy skategoryzowano. Inne pytania miały charakter zamknięty. Jedno z nich wymagało od dzieci dokonania wyboru jednego z trzech okresów życia. Miały one bowiem powiedzieć, kim najbardziej chciałyby być: a) dzidziusiem, b) osobą dorosłą, c) czy dzieckiem takim, jakim jest obecnie. W tym miejscu rozmowy podawano wiek dziecka, o który zapytano je na początku badania. Po dokonaniu wyboru proszono dzieci o jego uzasadnienie, zadając dwa pytania: „Dlaczego najbardziej chciałbyś/chciałabyś być...(np. dzieckiem)?”, „Dlaczego dobrze jest być...(np. dzieckiem)?”. Po uzyskaniu odpowiedzi proszono również dziecko o wyjaśnienie: „Dlaczego nie chciałbyś/chciałabyś być... (np. dzidziusiem)?”, „Dlaczego nie chciałbyś/chciałabyś być... (np. osobą dorosłą)?”, gdy dokonując wcześniej wyboru powiedziało ono, iż najbardziej chciałoby być dzieckiem takim, jakim jest teraz, a więc np. dzieckiem sześcioletnim lub dziesięcioletnim. Opisany wyżej fragment rozmowy z badanymi dziećmi wzorowany był na drugiej części testu „Zwierzyniec” René Zazzo i Tani Mathon (1974), w której zawarte są pytania dotyczące okresów życia. Z tego względu przedstawiono go dokładniej.

Badaniami objęto 341 osób, w tym 279 dzieci kończących edukację przedszkolną (I grupa) i 62 uczniów klasy trzeciej szkoły podstawowej (II grupa). Obie grupy badanych były zrównoważone, jeśli chodzi o liczbę dziewcząt i chłopców, a także ze względu na środowisko lokalne. Połowa badanych dzieci mieszkała w mieście i połowa na wsi. Badani uczęszczali do przedszkoli i szkół na terenie województwa lubelskiego. 


\section{WYNIKI BADAŃ}

Na początku prezentacji wyników czytelnikom należy się wyjaśnienie, dlaczego $\mathrm{w}$ ich referowaniu skupiono się jedynie na wskazywaniu różnic i podobieństw w postrzeganiu badanych kwestii przez dzieci kończące edukację przedszkolną oraz kończące edukację wczesnoszkolną. Otóż w toku analizy wypowiedzi ustalono, że zarówno płeć dzieci, jak i ich środowisko lokalne (miasto, wieś) nie różnicują w znaczący sposób obrazu dziecka i dzieciństwa. Z tego względu zrezygnowano z dokładnego przedstawienia w niniejszym opracowaniu tej części analizy wyników badań.

Prezentację obrazu dziecka i dzieciństwa w świadomości dzieci kończących edukację przedszkolną i wczesnoszkolną rozpoczęto od analizy ich wypowiedzi na temat tego, kogo, jaką osobę ich zdaniem można nazwać dzieckiem. Okazało się, iż najczęściej badani z obu grup dzieckiem określali osobę małą, a więc na pierwszy plan wysuwali wielkość (wzrost) dzieci. Tego rodzaju odpowiedzi w pierwszej grupie stanowiły 51\%, w drugiej zaś 35\%. Jedną czwartą odpowiedzi dzieci kończących edukację przedszkolną stanowiły te, w których porównywały one dziecko do siebie, mówiły, że dziecko to osoba „taka jak ja”. Znacznie rzadziej (10\%) takie odpowiedzi podawały dzieci kończące edukację wczesnoszkolną. One na drugim miejscu pod względem częstości występowania (28\%) podawały odpowiedź, że jest to osoba, która nie ma jeszcze 18 lat. Takie odpowiedzi u dzieci znajdujących się u progu edukacji szkolnej stanowiły tylko 3\%. Wskazuje to, iż dzieci starsze częściej zdają sobie sprawę, że granicę między dzieciństwem a dorosłością stanowi ukończenie 18 roku życia, co jest zgodne z literą prawa (Konwencja o prawach dziecka - Dz. U. 1991, nr 120, poz. 526, art.1). Dzieci kończące edukację wczesnoszkolną dosyć często (21\%) mówiły również, że dzieckiem jest osoba, która się uczy, chodzi do szkoły. W grupie dzieci młodszych tego typu odpowiedzi pojawiały się znacznie rzadziej (4\%). One częściej (16\%) niż dzieci starsze (3\%) mówiły, że dzieckiem jest osoba, która się bawi. W obu grupach zanotowano nieliczne wypowiedzi, które wskazują, iż niektóre dzieci zdają sobie sprawę, że dla rodziców „dzieckiem jest się zawsze”, „do końca życia”. Odpowiedzi tego typu w grupie dzieci młodszych stanowiły $1 \%$, zaś u starszych - 3\%. Tak więc z wiekiem rośnie liczba dzieci udzielających całkowicie poprawnych odpowiedzi (dzieckiem jest się do pełnoletności, a dla rodziców jest się nim zawsze). Maleje natomiast liczba odpowiedzi, w których kryterium jest cecha fizyczna (wzrost), praktykowane najczęściej aktywności (zabawa/nauka) oraz porównywanie ze sobą („taka jak ja”).

Zapytano też badanych jak długo jest się dzieckiem. Dzieci kończące edukację przedszkolną najczęściej (46\%) mówiły o czasie, kiedy chodzi się do przedszkola lub szkoły. Inne zaś zwracały uwagę na moment ukończenia szkoły (8\%). Spora grupa 
dzieci (21\%) stwierdzała, że dzieckiem jest dotąd, „dopóki się nie urośnie”. Wiek 18 lat, jako granicę dzieciństwa, wskazywało $9 \%$ badanych, zaś dla $4 \%$ z nich tę granicę stanowi moment rozpoczęcia pracy. Były też w grupie pierwszej dzieci, które mówiły, że dzieckiem jest się bardzo długo (7\%) oraz że jest się nim zawsze (5\%). W grupie dzieci kończących edukację wczesnoszkolną odpowiedzi na zamieszczone wyżej pytanie rozkładają się inaczej. Najczęściej (49\%) stwierdzały one, że dzieckiem jest się do 18 roku życia, 15\% mówiło, że jest się nim zawsze, 28\% wiązało okres dzieciństwa z chodzeniem do szkoły, zaś $7 \%$ określało je jako czas trwający bardzo długo.

Tak więc z wiekiem dzieci zmienia się sposób określania długości czasu bycia dzieckiem. Dzieci młodsze mówią przede wszystkim o czasie uczęszczania do przedszkola i szkoły oraz rośnięciu. Starsze zaś najczęściej wskazują górną granicę wieku dzieciństwa (18 lat) i podkreślają, że jest się nim zawsze. Dosyć dużo z nich, podobnie jak dzieci młodsze, czas dzieciństwa kojarzy z pobieraniem nauki w szkole.

Proszono również dzieci, by określiły, co to jest dzieciństwo. Według największej liczby dzieci z obu grup dzieciństwo to czas zabawy (37\% - I grupa; 30\% - II grupa). Trochę mniej dzieci określa ten okres jako czas, „kiedy chodzi się do przedszkola i szkoły", czas nauki i poznawania kolegów (13\% - I grupa; $21 \%$ - II grupa). $13 \%$ odpowiedzi w obu grupach stanowią te, w których zwraca się uwagę na wzrost i rozwój, jest to czas, „,kiedy się jest małym”, „kiedy się rośnie”. Są też dzieci, które mówią, że dzieciństwo to: czas miły, przyjemny, beztroski, bez obowiązków, kiedy nie trzeba pracować, czas radości. Te aspekty dzieciństwa podkreślają przede wszystkim dzieci starsze (15\%), rzadziej w ten sposób mówią dzieci z I grupy (4\%). W tej grupie częściej (6\%) niż w grupie II (3\%) zwraca się uwagę, iż jest to czas, kiedy dziećmi ktoś się opiekuje, kiedy przebywają z rodzicami, kiedy są rozpieszczane, $\mathrm{z}$ czego są bardzo zadowolone. $\mathrm{W}$ obu grupach pojawiały się, chociaż rzadko, wypowiedzi, z których przebijało niezadowolenie z okresu dzieciństwa, ponieważ jest to czas ograniczeń i zależności, „kiedy nie wszystko wolno”, „kiedy trzeba słuchać rodziców oraz pani w przedszkolu i szkole” (4\% - I grupa; $2 \%$ - II grupa). Stosunkowo duża liczba dzieci miała kłopoty z określeniem dzieciństwa. Jedne z nich mówiły: „nie wiem” (14\% - I grupa; 9\% - II grupa), inne zaś stwierdzały, iż dzieciństwo to czas, „kiedy jest się dzieckiem” (9\% - I grupa; 6\% - II grupa).

Aby dokładniej poznać doświadczenia dzieci związane z dzieciństwem proszono je o powiedzenie, co robi się w tym czasie. Analiza odpowiedzi wykazała, że dzieci z obu grup mówiły przede wszystkim o zabawie w domu i na świeżym powietrzu (60\%). Na drugim miejscu (20\%) wymieniane było chodzenie do przedszkola lub szkoły oraz nauka. Niektóre wspominały o dostępnych w tym czasie przyjemnościach (oglądanie bajek, telewizji, jeżdżenie na wycieczki - 6\%) oraz spędzaniu czasu z kolegami (6\%), a także o przebywaniu z rodzicami i czynnym uczestniczeniu w ich pracach (7\%). 
Starano się również ustalić, jak bardzo dla badanych osób atrakcyjny jest aktualnie doświadczany okres dzieciństwa w porównaniu z wiekiem niemowlęcym oraz dorosłością. W tym celu proszono każde dziecko, aby powiedziało, kim najbardziej chciałoby być: a) dzidziusiem, b) osobą dorosłą, c) czy dzieckiem takim, jakim jest obecnie, a także o uzasadnienie dokonanego wyboru i podania powodów odrzucenia pozostałych dwóch okresów życia. Z analizy wyborów wynika, że najwięcej (50\%) dzieci kończących edukację przedszkolną najbardziej chciałoby być osobą dorosłą, nieco mniej (43\%) - dzieckiem takim, jakim jest obecnie, zaś wiek niemowlęcy wybrało tylko $7 \%$ badanych osób. Nieco inaczej dokonywały wyborów dzieci kończące edukację wczesnoszkolną: 65\% z nich zadeklarowało, iż najbardziej chciałoby być dzieckiem takim, jakim jest obecnie, 32\% jako najbardziej atrakcyjny wybrało wiek osoby dorosłej, natomiast niemowlęciem wolałoby być tylko 3\% dzieci z tej grupy. Zauważamy więc, że z wiekiem wyraźnie wzrasta liczba osób, które wolą być dzieckiem w aktualnym okresie życia, zmniejsza się zaś liczba dzieci, dla których najbardziej atrakcyjnym okresem jest dorosłość. Prawidłowość ta potwierdziła się, gdy dzieci dokonywały wyboru tylko między aktualnym okresem życia a dorosłością. W takiej sytuacji więcej dzieci z obu grup uznało, że lepiej być dzieckiem aniżeli osobą dorosłą (55\% - I grupa; 65\% II grupa). Niżej przedstawię powody wybrania oraz odrzucenia poszczególnych okresów życia, zaczynając od korzyści i niedogodności bycia dzieckiem.

Dzieci w wieku przedszkolnym chcą być dzieckiem, ponieważ: mogą bawić się i atrakcyjnie spędzać czas (47\%); nie muszą pracować, nie mają obowiązków i zmartwień (20\%); mogą chodzić do przedszkola (19\%); mają różne przywileje i swobodę (robią, co chcą, mają wolny czas, fajnie jest być dzieckiem - 8\%); mogą mieć kolegów (5\%). Natomiast dzieci kończące edukację wczesnoszkolną mówią najczęściej o posiadaniu przywilejów (30\%), następnie o braku obowiązków i zmartwień, w tym o konieczności podejmowania pracy (18\%). W tej grupie pojawia się argument, że będą dłużej żyć, są zdrowi i nic im nie dolega (14\%). 10\% dzieci zwraca uwagę na możliwość zabawy i atrakcyjnego spędzania czasu i tyleż samo na posiadanie kolegów. Były również dzieci, które nie podały żadnego uzasadnienia swojego wyboru. Te zaś dzieci, które nie wskazały aktualnego okresu życia jako najbardziej atrakcyjnego, mówiły o pewnych niedogodnościach bycia dzieckiem, takich jak: konieczność chodzenia do przedszkola lub szkoły (33\% - I grupa; $40 \%$ - II grupa); brak takich praw, jakie mają dorośli (46\% - I grupa; 13\% - II grupa); brak swobody i konieczność posłuszeństwa wobec dorosłych (16\% - I grupa; $14 \%$ - II grupa); ponieważ nie podoba im się bycie dzieckiem (3\% - I grupa; 13\% - II grupa); a także dlatego, że mało wiedzą i umieją (2\% - I grupa). $20 \%$ dzieci z II grupy nie podało uzasadnień.

Oto jakie są, według badanych dzieci, blaski i cienie bycia dorosłym. Dzieci kończące edukację przedszkolną uważają, że dobrze jest być dorosłym, ponieważ: 
są niezależni, mogą robić, co chcą (32\%); pracują i zarabiają (29\%); mogą kierować samochodem (12\%); mogą modnie się ubierać, malować, chodzić na wysokich obcasach (6\%); mogą się kimś opiekować, komuś pomagać, mieć dzieci (6\%); dorośli mogą rozkazywać (3\%); mogą wykonywać wymarzony zawód (2\%); nie muszą się uczyć, chodzić do przedszkola/szkoły (2\%). Ponadto niektóre dzieci chcą być dorosłymi, ponieważ chcą być starsze i duże (3\%). Badani z drugiej grupy mówią przede wszystkim o samodzielności, swobodzie i większych możliwościach osób dorosłych w porównaniu z dziećmi (jazda samochodem, rozkazywanie, chodzenie na obcasach, malowanie się - 81\%); następnie o braku obowiązku szkolnego (14\%) lub, że dorosłość to okres fajniejszy niż dzieciństwo (3\%). Dorosłość ma też swoje cienie. Wskazują na nie wypowiedzi dzieci, które nie wybrały tego okresu jako najbardziej atrakcyjnego, argumentując, iż dorośli muszą chodzić do pracy (46\% - I grupa); mają nadmiar obowiązków i problemów (33\% - I grupa; $75 \%$ II grupa); nie mogą się bawić (17\% - I grupa); lepiej być dzieckiem (2\% - I grupa; $13 \%$ - II grupa); dorośli często się złoszczą (2\% - I grupa); bolą ich kości, nie mają siły, wcześniej będą starzy, szybciej umrą (2\% - II grupa).

Okres niemowlęctwa jako najbardziej atrakcyjny wybrała mała liczba dzieci. Dla nich korzyści z bycia niemowlęciem to przede wszystkim brak konieczności chodzenia do przedszkola lub szkoły oraz brak obowiązków (57\% - I grupa; 50\% - II grupa). Pozostałe dzieci wybór tego okresu uzasadniają dużą dozą miłości i zainteresowania rodziców małym dzidziusiem. Osoby, które odrzuciły ten okres życia, a uczyniła to zdecydowana większość badanych dzieci, wskazywały na następujące niedogodności: brak samodzielności i nieporadność - „bo nie umie chodzić, mówić, rysować, samo się bawić, nic nie wie, nie umie” (43\% - I grupa; $41 \%$ - II grupa); brak możliwości uczestniczenia w atrakcyjnych zajęciach - „bo nie bawi się lalką, samochodem, nie jeździ rowerem, nie spotyka się z kolegami, nie chodzi do szkoły" (20\% - I grupa; 32\% - II grupa); dokuczliwość dla innych „bo płacze, krzyczy, sika w majtki, drapie, gryzie” (24\% - I grupa; 12\% - II grupa). Niektóre też mówiły, iż nie chcą być dzidziusiem, ponieważ już nim były.

Kolejne pytania dotyczyły swobody i samodzielności dzieci. W odpowiedzi na pytanie, co wolno robić $\mathrm{w}$ dzieciństwie, dzieci z obu grup wymieniały podobne czynności. Najczęściej mówiły o swobodnej zabawie w domu i na świeżym powietrzu z wykorzystaniem różnych zabawek, przyborów i sprzętów (samochody, klocki, lalki, rower, piłka, guma, rolki, trampolina itp.). Wiele dzieci, zwłaszcza starszych, podkreślała możliwość spotykania się i zabawy z kolegami. Do dozwolonych czynności zaliczyły też rysowanie, malowanie, czytanie, korzystanie z urządzeń elektronicznych (oglądanie bajek, granie na komputerze). Były też takie dzieci, które mówiły, iż w dzieciństwie wolno robić wszystko, na co zgodzą się rodzice. Inne stwierdzały, że nie ma żadnych ograniczeń, można robić wszystko, 
co się chce, a jeszcze inne, że bardzo mało, prawie nic. Można więc powiedzieć, że ocena zakresu swobody jest bardzo zróżnicowana. Odpowiadając na pytanie, co robią samodzielnie, dzieci z obu grup wymieniały przede wszystkim zabawy oraz czynności samoobsługowe. Ponadto dzieci w młodszym wieku szkolnym mówiły często o samodzielnym korzystaniu z urządzeń elektronicznych oraz zajęciach związanych z obowiązkiem szkolnym (chodzenie do szkoły, odrabianie lekcji, uczenie się, czytanie, malowanie).

Zapytano również dzieci o obowiązki w okresie dzieciństwa. Dzieci z obu grup zaliczały do nich najczęściej chodzenie do przedszkola i szkoły oraz uczenie się. Ponadto badane dzieci uważają, iż do ich obowiązków należy słuchanie się rodziców oraz pomaganie im, a także radzenie sobie w samoobsłudze i utrzymaniu porządku wśród swoich rzeczy. Niektóre dzieci do obowiązków zaliczają również zabawy. Ale były też takie, które stwierdzały, że dzieci nie mają obowiązków, nie muszą nic robić.

Pytano również dzieci o ograniczenia w okresie dzieciństwa, a więc o to, czego w tym czasie robić nie wolno. Do czynności zabronionych obie grupy dzieci zaliczają takie same ich rodzaje. Należą do nich przede wszystkim zachowania zagrażające bezpieczeństwu typu: zabawy z ogniem, zapałkami, gazem, prądem, wspinanie się na drzewa, meble, nieostrożne korzystanie z urządzeń na placu zabaw, przechodzenie przez jezdnię, otwieranie drzwi mieszkania obcym osobom itp. Zakazane jest także nieposłuszeństwo wobec dorosłych, bycie niegrzecznym oraz zachowanie agresywne (bicie kolegów, szczypanie, przezywanie, przedrzeźnianie, kłócenie się, używanie brzydkich słów). Niektóre dzieci zwracają uwagę, że zabronione jest również palenie papierosów, picie wódki oraz długie korzystanie z urządzeń elektronicznych.

Kolejna grupa pytań dotyczyła radości, marzeń i zmartwień dzieci. Analiza wypowiedzi wykazała, że dzieci z obu grup czują się szczęśliwe zwłaszcza wtedy, kiedy mogą się bawić oraz gdy otrzymują na coś pozwolenie, np. mogą wyjść na dwór, a także wtedy, gdy dostają prezenty. Radość sprawia również dzieciom przebywanie i zabawa $\mathrm{z}$ kolegami oraz spędzanie czasu z rodzicami i wyrazy ich uznania oraz miłości („kiedy są z rodzicami”, „bawią się z tatą”, „gdy tata wraca”, "gdy mama przytula", „gdy mama chwali”). Niektóre dzieci w młodszym wieku szkolnym cieszą się też wtedy, gdy osiągają sukcesy („gdy dostają dobre oceny”, „gdy im coś wyjdzie, uda się").

Marzenia dzieci z obu grup dotyczą przede wszystkim posiadania nowych rzeczy (zabawki, przybory i urządzenia do zabaw, gier oraz atrakcyjnego spędzania czasu). Część dzieci mówi też o tym, kim chciałoby zostać w przyszłości (np.: gwiazdą rocka, księżniczką, kosmonautą, strażakiem, piłkarzem, rajdowcem, policjantem, nauczycielem, lekarzem, opiekunką kotów, ogrodnikiem, paleontologiem, geniuszem, 
osobą sławną, gwiazdą). Niektóre również marzą o niezależności, byciu dorosłym i o zwolnieniu z obecnych obowiązków. Tylko nieliczne wspominają o sukcesach w nauce („o dobrych stopniach w szkole”, „by wyrosnąć na kogoś mądrego”).

Jeśli chodzi o zmartwienia w okresie dzieciństwa, to na początku zapytano, czy dzieci je mają, a następnie proszono o ich wymienienie. Okazało się, że $26 \%$ dzieci kończących edukację przedszkolną uważa, iż dzieci nie mają żadnych zmartwień. Taką opinię wyraziło też $11 \%$ dzieci w młodszym wieku szkolnym. Pozostałe twierdziły, iż dzieci mają zmartwienia i podawały, jakie są ich powody. $\mathrm{Z}$ analizy wypowiedzi wynika, iż dzieci w wieku przedszkolnym martwią się przede wszystkim wtedy, gdy rodzice stosują wobec nich zakazy, kary i ograniczenia. Innym powodem do zmartwień są niesatysfakcjonujące kontakty z kolegami (np.: „gdy ktoś nie chce się ze mną bawić”, „zabiera zabawkę”, „bije”). Przyczyną zmartwień dzieci z tej grupy są też różnego rodzaju urazy i skaleczenia. Niektóre dzieci jako powód zmartwień podają chorobę rodziców lub innych członków rodziny. Powodem zmartwienia jest też rozłąka i tęsknota za rodzicami. U dzieci kończących edukację wczesnoszkolną na pierwszy plan wybijają się zmartwienia związane ze szkołą (np. złe oceny, spóźnienie na lekcje, zapomnienie o pracy domowej). Martwią się też one z powodu niezadowalających kontaktów z kolegami oraz zakazów rodziców. U dzieci tych, podobnie jak u młodszych, pojawiają się nieliczne wypowiedzi, w których ujawnia się troska związana ze zdrowiem własnym lub członków rodziny.

\section{PODSUMOWANIE I WNIOSKI}

Przedstawione wyniki badań pozwalają scharakteryzować dziecko i dzieciństwo w świetle wypowiedzi dzieci kończących edukację przedszkolną i wczesnoszkolną i odpowiedzieć na wcześniej sformułowane pytania badawcze. Otóż dziecko to osoba, która opisywana jest przez badanych przez odwołanie się do analogii („taka jak ja”); wskazanie na cechy wyglądu zewnętrznego („mała”); dokonujące się w niej przemiany („rośnie, rozwija się”) oraz typowe dla niej czynności, obowiązki i aktywności („chodzi do przedszkola i szkoły, bawi się i uczy”). Dzieckiem jest się stosunkowo długo („dopóki się nie urośnie, chodzi do szkoły, nie pracuje, ma się mniej niż 18 lat"), a dla rodziców jest się nim zawsze.

Dzieciństwo zaś to czas zabawy, chodzenia do przedszkola i szkoły, czas nauki i poznawania kolegów, kiedy jest się małym, rozwija się. Jest to dla dzieci czas miły, przyjemny, beztroski, wypełniony zajęciami sprawiającymi radość i zadowolenie (gry i zabawy, wycieczki, oglądanie bajek, spotykanie się z kolegami, przebywanie $\mathrm{z}$ rodzicami). Jest to okres bardzo atrakcyjny dla większości dzieci i akceptowany 
przez nie, ponieważ można się bawić, nie musi się pracować, ma się dużo przywilejów, nie ma się obowiązków i zmartwień, którymi obciążone są osoby dorosłe.

Okres dorosłości jawi się również wielu dzieciom jako czas wielce atrakcyjny, gdyż osoby dorosłe są niezależne, mogą decydować o sobie i innych. Najmniej atrakcyjny dla zdecydowanej większości dzieci jest natomiast okres niemowlęctwa, przede wszystkim dlatego, że dziecko w tym czasie jest nieporadne, niesamodzielne oraz uciążliwe dla innych.

Swoboda i samodzielność w okresie dzieciństwa mają, zgodnie z wypowiedziami badanych, ograniczony zakres. Dotyczą one głównie zabaw oraz korzystania z zabawek i urządzeń służących przyjemnemu spędzaniu czasu, a także odnoszą się do zajęć i czynności związanych z samoobsługą i wypełnianiem obowiązku szkolnego. Podobny zakres i charakter mają powinności dzieci w okresie dzieciństwa, a więc to, co muszą robić. Należy do nich uczęszczanie do przedszkola i szkoły, samoobsługa oraz posłuszeństwo wobec dorosłych. Zabronione natomiast są w okresie dzieciństwa wszelkie zachowania zagrażające bezpieczeństwu dziecka, narażające ich zdrowie i życie, a także zachowania sprawiające ból i cierpienie innym, zwłaszcza zachowania agresywne wobec kolegów.

Powodem do radości i obiektem marzeń dzieci jest głównie wszystko to, co wiąże się z zabawą oraz pomnażaniem aktualnego stanu posiadania atrakcyjnych przedmiotów, zwłaszcza zabawek, a także zwiększania swobód i polepszania warunków do nieskrępowanej zabawy i przyjemnego spędzania czasu. Zmartwień natomiast dzieci nie mają, a jeśli się już pojawiają, to ich powodem są przede wszystkim różne zakazy i ograniczenia ze strony dorosłych, a także trudności $\mathrm{w}$ kontaktach $\mathrm{z}$ kolegami.

Badania wykazały, że dziecko i dzieciństwo jest opisywane podobnie zarówno przez dziewczynki, jak i chłopców. Nie stwierdzono też wyraźnych różnic w wypowiedziach, opisach i ustosunkowaniach dotyczących dziecka i dzieciństwa, które prezentowane były przez dzieci mieszkające $\mathrm{w}$ środowisku miejskim i wiejskim. Obraz dziecka i dzieciństwa zmienia się natomiast $\mathrm{z}$ wiekiem i etapem kształcenia dzieci, które to czynniki sprzyjają wzbogacaniu i poszerzaniu ich wiedzy, doświadczeń i przeżyć. Dla dzieci młodszych jest to przede wszystkim czas zabawy, atrakcyjnego spędzania czasu, pozytywnych doznań i realizacji pragnień związanych z zabawą - główną i dominująca formą aktywności w tym okresie życia, a także czas doświadczania opieki i życzliwego zainteresowania ze strony dorosłych. Jest to również czas niewielkich i mało zróżnicowanych obowiązków oraz ograniczonej samodzielności. Tego rodzaju doświadczenia dzieci mogą powodować, iż niektóre z nich wszelkie ograniczenia swobody oraz oczekiwanie wypełniania przez nie ustalonych powinności czy konieczność respektowania zakazów oraz zasad współżycia społecznego traktują jako uciążliwe. 
Z wypowiedzi dzieci kończących edukację wczesnoszkolną wyłania się nieco mniej sielankowy i bardziej realistyczny obraz dziecka i dzieciństwa. Częściej zdają sobie one sprawę, że dzieciństwo przemija, kończy się wraz z osiągnięciem pełnoletności (18 lat), że tylko w tym okresie ma się dużo przywilejów i swobody a mało obowiązków, zmartwień i problemów, którymi obciążone są osoby dorosłe. Dzieci te częściej zauważają, że ich podstawową powinnością jest wypełnianie obowiązków związanych z uczęszczaniem do szkoły, a dla niektórych z nich sukcesy w nauce są źródłem radości oraz przedmiotem marzeń.

$\mathrm{Z}$ analizy treści wypowiedzi większości badanych dzieci wyłania się więc ogólnie pozytywny obraz dziecka i dzieciństwa, ukształtowany, jak można sądzić, w wyniku przewagi w ich dotychczasowym życiu przeżyć satysfakcjonujących nad doświadczeniami negatywnymi. I choć z wypowiedzi tych przebija dosyć często nastawienie egocentryczne i hedonistyczne oraz dążność do maksymalizowania przyjemności i minimalizowania problemów i trudności, a także ujawniają się w nich niektóre oznaki postawy roszczeniowej i konsumeryzmu, to jednak dzieci zdają sobie sprawę z tego, iż w dzieciństwie są również obowiązki i konieczność respektowania podstawowych zasad współżycia społecznego.

Analizując wypowiedzi dzieci, można odnieść wrażenie, że większość z nich trzymana jest $\mathrm{w}$ rodzinach $\mathrm{z}$ dala od trudów i problemów życia rodzinnego. Świat dzieci koncentruje się wokół zabawy, kontaktów z kolegami oraz nielicznych obowiązków, pojawiających się wraz z chodzeniem do przedszkola lub szkoły. Związane to jest zapewne $\mathrm{z}$ ich wiekiem oraz pojmowaną $\mathrm{w}$ ten sposób przez rodziców troską o ich dobro i szczęśliwe dzieciństwo. Jednakże wychowanie wyłącznie w klimacie beztroski, przyjemności, nieustannej zabawy i stałego chronienia dzieci przez dorosłych przed sytuacjami trudnymi może budować w ich świadomości niepełny i fałszywy obraz rzeczywistości. Dlatego już w wieku przedszkolnym i wczesnoszkolnym należy zadbać o rozszerzanie wiedzy, doświadczeń i przeżyć dzieci dotyczących życia społecznego. Pomocna może być w tym m.in. literatura dla dzieci, którą mogą wykorzystywać rodzice i nauczyciele do ukazywania, jak złożone, rozmaite i trudne niekiedy mogą być relacje między ludźmi, zarówno w kręgu dorosłych, jak i dzieci, jakie jedni i drudzy miewają kłopoty i zmartwienia, jakie dotykają ich problemy oraz jak sobie z nimi radzą. Literatura ta może ułatwić zdobywanie przez nie wiedzy o świecie oraz kształtowanie ich wrażliwości emocjonalnej oraz postaw społeczno-moralnych. Umożliwia ona bowiem stworzenie bezpiecznego dystansu w czasie wspólnego $\mathrm{z}$ dorosłymi analizowania przedstawionych w niej fikcyjnych zdarzeń i sytuacji, kiedy to dzieci skłaniane są do wnikania w motywy działań różnych postaci literackich, rozpatrują możliwe sposoby postępowania, zastanawiają się nad konsekwencjami zachowań. Identyfikacja zaś z bohaterami sprawia, że fikcyjne problemy nabierają dla dzieci coraz 
bardziej osobistego znaczenia. Dzięki temu zaczynają one coraz lepiej rozumieć złożoność świata i kontaktów między ludźmi, próbują odnosić swoją wiedzę do autentycznych zdarzeń i brać ją pod uwagę w swoim postępowaniu. Sprzyja to stopniowemu przekształcaniu się oczekiwań społecznych w indywidulany i trwały system wartości dzieci.

\section{LITERATURA}

Appelt K., 2001, Dziecko i dzieciństwo w oczach dorosłego. W: D. Kornas-Biela (red.), Oblicza dzieciństwa. Lublin, Wydawnictwo Towarzystwa Naukowego KUL.

Aries P., 2010, Historia dzieciństwa. Warszawa, Wydawnictwo Aletheia.

Didkowska B., 2015, Rysunek dziecka w wieku od 3 do 12 lat a język wizualny nowych mediów. Toruń, Wydawnictwo Naukowe UMK.

Konwencja o prawach dziecka (Dz.U. 1991, nr 120, poz. 526, art. 1).

Matyjas B., 2008, Oblicza dzieciństwa we współczesnych rodzinach polskich. W: B. Muchacka, K. Kraszewski (red.), Dziecko w świecie współczesnym. Kraków, Oficyna Wydawnicza Impuls.

Nowak J., 2013, Kategoria dzieciństwa i jej pedagogiczno-społeczne aspekty. „Rozprawy Naukowe i Zawodowe PWSZ w Elblągu", z. 17.

Segiet K., 2011, Dziecko i jego dzieciństwo w perspektywie naukowego poznania i doświadczanie rzeczywistości. Poznań, Wydawnictwo Naukowe UAM.

Smolińska-Theiss B., 1993, Dzieciństwo w matym mieście. Warszawa, Wydawnictwo UW. Smolińska-Theiss B., 2010, Rozwój badań nad dzieciństwem - przełomy i przejścia. „Chowanna”, nr 1.

Śliwerski B., 2007, Pedagogika dziecka. Studium pajdocentryzmu. Gdańsk, GWP. Vasta R., Haith M.M., Miller S.A., 2004, Psychologia dziecka. Warszawa, WSiP. Zazzo R., Mathon T., 1974, Zwierzyniec. W: R. Zazzo (red.), Metody psychologicznego badania dziecka. Warszawa, PZWL.

Zwiernik J., 2008, Nauczyciel wobec niejednoznaczności kategorii „dziecko”. W: B. Muchacka, K. Kraszewski (red.), Dziecko w świecie współczesnym. Kraków, Oficyna Wydawnicza Impuls. 
CHILD AND CHILDHOOD IN THE PERCEPTION

OF CHILDREN FINISHING PRE-SCHOOL AND EARLY CHILDHOOD EDUCATION

\begin{abstract}
Child and childhood are categories that are difficult to define as they gain different meanings depending on changing historical periods, cultural and environmental circles and scientific theories developed within different scientific disciplines. These meanings significantly influence the situation of the child in society at a specific place and time, as well as the shape and quality of his relationships with adults and the life experiences he gains. The study presents a picture of a child and his childhood formed in the awareness of modern children finishing pre-school and early childhood education. The basis for this picture was an analysis of children's responses to the questions asked during individual interviews.
\end{abstract}

Keywords: child, childhood, periods of life 